\title{
Methylenetetrahydrofolate Reductase Gene C677T Polymorphism and Its Association with Ovary Cancer
}

\author{
Vandana Rai \\ Human Molecular Genetics Laboratory, Department of Biotechnology, VBS Purvanchal University, Jaunpur-222003, India
}

\begin{abstract}
Methylenetetrahydrofolate reductase (MTHFR) is a vital enzyme involved in folate metabolism; a single nucleotide polymorphism (SNP) C677T has been reported to be linked with altered incidences of several diseases. The association between ovary cancer and the MTHFR gene C677T polymorphism has been investigated in several case-control studies. These studies rendered contradictory results, to shed light on these inconclusive findings, a meta-analysis of all available studies relating the C677T polymorphism to the risk of ovary cancer was conducted. The following electronic databases were searched without language restrictions: Pubmed, Google Scholars, Elsevier and Springer Link up to December, 2014. Odds ratios (ORs) with their $95 \%$ confidence intervals (95\% Cls) were calculated. Meta-analysis was performed using Mix version 1.7.

Eleven studies were finally included in present meta-analysis, which contained 5922 individuals with ovary cancer and 5235 healthy controls. There was not significant relationship between MTHFR C677T polymorphism and ovary cancer under allele contrast (OR: 1.05, 95\% Cl: 0.99-1.11), dominant (OR: 1.02, 95\% Cl: 0.91-1.13), recessive (OR: 0.99, 95\% Cl: 0.90-1.08), homozygous (OR: 0.99, 95\% Cl: 0.86-1.14) and co-dominant/heterozygous (OR: $1.02,95 \%$ $\mathrm{Cl}$ : 0.91-1.14) genetic models. Subgroup analysis also reached similar results. Sensitivity analysis indicated that the overall result were dependable.
\end{abstract}

In conclusion, results of present meta-analysis showed that MTHFR gene C677T polymorphism is not a risk factor for Ovary cancer.

Keywords: Ovary cancer; MTHFR; C677T; Polymorphism; Metaanalysis

\section{Introduction}

Cancer is a leading cause of death worldwide. It is estimated that the burden of cancer will increase up to 22.2 million new cases diagnosed annually worldwide by 2030 , which represents an increase by $75 \%$ Compared with the statistics of 2008 [1,2]. Ovarian cancer is the most common cause of death from gynecological malignancies. In the early stages, women are generally asymptomatic or have non-specific symptoms, making early stage ovarian cancer difficult to diagnose [2-6]. It is the ninth most common malignancy and the fifth most common cause of death from female cancers in the United States [6].

The wide geographic variation in incidence rates points to the role of genetic and environmental factors in the pathogenesis of this cancer. Possible risk factors for ovarian cancer include family history, tobacco smoking, infertility, low parity, and hormone replacement therapy, while oral contraceptive use and fewer menstrual cycles are associated with decreased risk [7-9]. Deficiency of nutrients, such as vitamins and microelements, has also been associated with increased risk for ovarian cancer, whereas high fruit and vegetable intake may help prevent the disease $[9,10]$. The incidence rate varies geographic worldwide. The wide geographic variation at international levels of ovarian cancer in terms of incidence and mortality suggested the role of genetic and environmental factors in the pathogenesis of this cancer [11].

Folate has a key role in DNA synthesis and methylation, thus, adequate intake is essential to maintain DNA integrity, and its deficiency may increase the risk of mutation, and hence cancer, therefore many countries have introduced mandatory or voluntary fortification of grain products with folic acid. Low folate intake has been associated with an increased risk of several cancers, including breast, and endometrial cancer $[8,12-14]$. Its influence on ovarian cancer risk is less clear [13,15-17] and may depend on other unmeasured factors such as genetic variation in the folate metabolism pathway [18]. Folate availability for DNA synthesis and as a methyl donor for methylation depends not only on intake, but also on the activity of enzymes, including methylene tetrahydrofolate reductase (MTHFR), methionine synthase (MTR) and MTR reductase (MTRR) $[18,19]$.

Methylenetetrahydrofolate reductase (MTHFR) is the enzyme responsible for the reduction of methylenetetrahydrofolate. Reduced MTHFR activity results in an increased requirement for folic acid to maintain normal homocysteine remethylation to methionine. In the absence of sufficient folic acid, intracellular homocysteine accumulates, methionine resynthesis is reduced and remethylation reactions are interrupted. Increased homocysteine and decreased methionine cause decreased SAM to S-adenosylhomocysteine (SAH) ratio, which takes part in methylation [20]. There are more than 40 polymorphisms reported in MTHFR gene and among them C677T variant is the most studied and clinically important. The C677T variant (rs 1801133; Ala $222 \mathrm{Val}$ ) has been associated with a decreased activity of MTHFR, and increased homocysteine level [21-23]. Mutant homozygous (TT) individuals have a decreased enzymatic activity $~ 70 \%$ and the heterozygote by $40 \%$. A dysfunctional MTHFR leads to lower levels of SAM resulting into DNA hypomethylation. DNA hypomethylation increases the risk of many diseases and disorders like-neural tube

*Corresponding author: Vandana Rai, Human Molecular Genetics Laboratory, Department of Biotechnology, VBS Purvanchal University, Jaunpur-222003, India Tel: 05452-252222; Fax: 05452-252244; E-mail: raivandana@rediffmail.com

Received January 06, 2016; Accepted May 07, 2016; Published May 14, 2016

Citation: Rai V (2016) Methylenetetrahydrofolate Reductase Gene C677T Polymorphism and Its Association with Ovary Cancer. J Health Med Informat 7: 226. doi:10.4172/2157-7420.1000226

Copyright: @ 2016 Rai V . This is an open-access article distributed under the terms of the Creative Commons Attribution License, which permits unrestricted use, distribution, and reproduction in any medium, provided the original author and source are credited. 
defects [24], cleft lip and palate [25], cardiovascular diseases [21], diabetes [26] and cancer [27] etc.

The different investigations reported the effect of MTHFR C677T polymorphism on ovarian cancer risk in different ethnicities may be due to differences in population background, study design, sample size, environmental factors, and chance variations. Further confirmation of such differential effects is therefore needed. Hence a meta-analysis was carried out to come to a conclusive result whether C677T polymorphism is a risk factor for ovary or not.

\section{Methods}

\section{Selection of studies}

Electronic searches were conducted using PubMed, Google Scholar, Elsevier and Springer link and all published manuscripts up to March, 2014 were considered in present meta-analysis. The following index terms were used for search 'MTHFR' 'Methylenetetrahydrofolate reductase', and 'C677T polymorphism', and 'Ovary cancer'. In addition, bibliographies of all articles and reviews were hand searched for additional suitable studies.

\section{Data extraction}

The following information was extracted from each eligible study: first author's name, journal name, year of publication, country name, number of cases and controls and genotyping method. Number of alleles or genotypes in both cases and controls were extracted or calculated from published data to recalculate ORs.

\section{Inclusion and exclusion criteria}

The inclusion criteria of studies were as follow: studies should: 1) Be original, 2) Used case control approach 3) Used PCR-RFLP method for MTHFR genotype analysis and 4) Published in a peer-reviewed journal. Studies were excluded if: 1) Their sample was not independent from that investigated in another study, 2) Incomplete raw data information and not providing complete information for number of allele and/or genotype calculation, 3) Studies based on pedigree data were excluded as they investigate linkage and not association.

\section{Statistical analysis}

The present meta-analysis examined the overall association of mutant $\mathrm{T}$ allele with the risk of ovary cancer relative to the $\mathrm{C}$ allele. The associations were indicated as odds ratios (ORs) with the corresponding $95 \%$ CI. A pooled OR was then estimated on the basis of the individual ORs. The OR was estimated either by using fixed effect [28] or random effect [29] models depending upon heterogeneity. When there is considerable heterogeneity between studies then the pooled OR is preferably estimated using the RE model [30]. Models were chosen based on the method described by Thakkinstian et al. [31], briefly calculating and comparing the ORs of $\mathrm{T}$ vs. $\mathrm{C}$ (allele contrast/additive), TT vs. CC (homozygote), CT vs. CC (co-dominant), TT+CT vs. CC (dominant) and TT vs. CT+CC (recessive) checking the heterogeneity and significance, then determining the best model.

The heterogeneity between studies was tested using the Q-statistic and heterogeneity between studies was quantified using the $\mathrm{I}^{2}$ statistic $[32,33]$. If $\mathrm{I}^{2}>50 \%$ then random effect model was used (which gives wider confidence intervals) otherwise fixed effect model applied. Cumulative meta-analysis was also performed to observe the effect of subsequent addition of each study. Sensitivity analysis was performed to explore potential heterogeneity and verify the stability and robustness of the main results. Quality of each study was assessed using methodological quality assessment scale according to the methods of Guo et al. [34]. Five major components were judged like: cases diagnosis, source of controls, sample size, quality control of genotyping methods and Hardy-Weinberg equilibrium assessment in controls.

\section{Publication bias}

Publication bias was investigated by using funnel plots; viz. funnel plot of standard error by log odds ratio and funnel plot of precision (1/ standard error) by log odds ratio. Different statistical tests such as Begg and Mazumdar rank correlation [35] and Egger's regression intercept [36] were adopted to assess the publication bias. All $\mathrm{p}$ values are two tailed with a significance level at 0.05 . All statistical analyses were undertaken using the freely available program MIX version 1.7 [37].

\section{Results \\ Eligible studies}

Following these exclusions, 9 individual case-control studies with a total of 5,922 cases and 5,235 controls were included into this metaanalysis $[9,11,18,19,38-42]$. One author 18 collected case samples from three different centers (New England Case Control Study (NEC), Nurses' Health Study (NHS), and Mayo Clinic Ovarian Cancer Case Control Study (MAY)) and reported separately in article, so they were included as separate three studies. Hence, total numbers of 11 studies were included in the present meta-analysis. Three studies investigated Asian population $[9,11,40]$ and other studies investigated Caucasian population $[18,19,38,39,41,42]$.

\section{Characteristics of included studies}

In total 11 studies, total cases were 5,922 with CC (3032), CT (2308) and TT (582), and controls were 5,235 with CC (2511), CT (2176), and TT (548). In controls genotypes percentage of CC, CT and TT were $47.97 \%, 41.57 \%$ and $10.47 \%$ respectively. In total cases genotype percentage of CC, CT and TT was $51.2 \%, 39 \%$ and $9.8 \%$ respectively. Frequencies of CC and CT genotypes were highest in both cases and controls (Table 1). Number of $\mathrm{C}$ and $\mathrm{T}$ alleles were also calculated and presented in Table 2. Five studies did not show any association (Jakubowska et al.; Terry et al.; Webb et al.; Pawlik et al.) and odds ratio was above one in other studies [18,19,38,39,42].

\section{Meta-analysis:}

The main analysis for investigating the association of the C677T allele $\mathrm{T}$ and the risk of developing ovary cancer relative to the allele $\mathrm{C}$ showed higher heterogeneity $\left(\mathrm{P}=0.0009, \mathrm{I}^{2}=65.2 \%\right)$ between the 11 studies; the fixed and random pooled $\mathrm{OR}$ did not significantly associated with ovary cancer $(\mathrm{OR}=1.04,95 \% \mathrm{CI}=0.99-1.11, \mathrm{p}=0.90)$ and $(\mathrm{OR}=1.08,95 \% \mathrm{CI}=0.95-1.22, \mathrm{p}=0.15)$.

The genotype differences for the homozygotes (TT vs. CC) revealed moderate heterogeneity $\left(\mathrm{P}=0.0002, \mathrm{I}^{2}=69.55 \%\right)$ and did not show any significant association either with fixed effect $(\mathrm{OR}=0.99,95 \% \mathrm{CI}=0.86-1.14$, $\mathrm{p}=0.90)$ or random effect model $(\mathrm{OR}=1.02,95 \% \mathrm{CI}=0.75-1.37, \mathrm{p}=0.91)$. Similarly, genotype contrast using co-dominant, dominant and recessive models also did not show any significant association (CT vs. CC OR=1.01, 95\% $\mathrm{CI}=0.85-1.20, \mathrm{p}=0.90$; $\mathrm{TT}+\mathrm{CT}$ vs. $\mathrm{CC} \mathrm{OR}=1.01,95 \% \mathrm{CI}=0.83-1.21$, $\mathrm{p}=0.93$; TT vs. $\mathrm{CT}+\mathrm{CC} \mathrm{OR}=1.03,95 \% \mathrm{CI}=0.85-1.23, \mathrm{p}=0.76$ )

\section{Statistical analysis}

In allele contrast meta-analysis, sensitivity analysis performed by exclusion of the studies in which control population was not in Hardy Weinberg equilibrium, studies with small sample size $(<100)$ and 
Citation: Rai V (2016) Methylenetetrahydrofolate Reductase Gene C677T Polymorphism and Its Association with Ovary Cancer. J Health Med Informat 7: 226. doi:10.4172/2157-7420.1000226

Page 3 of 8

\begin{tabular}{|c|c|c|c|c|}
\hline Study & Ethnicity & Case & Control & References \\
\hline Jakubowska et al. [38] & Caucasian & 144 & 280 & Breast Cancer Res Treat 104: 299-308 \\
\hline Wu et al. [40] & Asian & 81 & 80 & Xian Dai Fu Chan Ke Jin Zhan 16: 811-813 \\
\hline Terry (NEC) et al. [18] & Caucasian & 1059 & 1125 & Gynecol Oncol 119: 319-324 \\
\hline Terry (NHS) et al. [18] & Caucasian & 153 & 482 & Gynecol Oncol 119: 319-324 \\
\hline Terry (MAY) et al. [18] & Caucasian & 364 & 412 & Gynecol Oncol 119: 319-324 \\
\hline Webb [19] & Caucasian & 1668 & 1278 & Eur J Clin Nutr 65: 1133-1140 \\
\hline Prasad and Wilkhoo [41] & Caucasian & 80 & 125 & Onkologie 34: 422-426 \\
\hline Gao et al. [11] & Asian & 224 & 432 & Asian Pac J Cancer Prev 13: 569-573 \\
\hline Jakubowska et al. [38] & Caucasian & 1664 & 483 & Br J Cancer 106: 2016-2024 \\
\hline Pawlik et al. [42] & Caucasian & 135 & 160 & Mol Biol Rep 39: 5553-5560 \\
\hline Zhang et al. [9] & Asian & 215 & 218 & Int J Mol Sci 13: 4009-4020 \\
\hline
\end{tabular}

Table 1: Characteristics of eleven studies included in the present meta-analysis

\begin{tabular}{|c|c|c|c|c|c|c|c|c|c|c|}
\hline \multirow{2}{*}{ Study } & \multicolumn{2}{|c|}{ CC genotype } & \multicolumn{2}{|c|}{ CT genotype } & \multicolumn{2}{|c|}{ TT genotype } & \multicolumn{2}{|c|}{ C allele } & \multicolumn{2}{|c|}{ T allele } \\
\hline & Case & Control & Case & Control & Case & Control & Case & Control & Case & Control \\
\hline Jakubowska et al. [38] & 73 & 128 & 56 & 134 & 15 & 18 & 202 & 390 & 86 & 170 \\
\hline Wu et al. [40] & 17 & 32 & 40 & 35 & 24 & 13 & 74 & 99 & 88 & 61 \\
\hline Terry (NEC) et al. [18] & 427 & 499 & 492 & 488 & 140 & 138 & 1346 & 1486 & 772 & 764 \\
\hline Terry (NHS) et al. [18] & 71 & 210 & 72 & 217 & 10 & 55 & 214 & 637 & 92 & 327 \\
\hline Terry (MAY) et al. [18] & 164 & 193 & 167 & 168 & 33 & 51 & 495 & 554 & 233 & 270 \\
\hline Webb [19] & 774 & 571 & 709 & 568 & 185 & 139 & 2257 & 1710 & 1079 & 846 \\
\hline Prasad and Wilkhoo [41] & 72 & 116 & 3 & 8 & 5 & 1 & 147 & 240 & 13 & 10 \\
\hline Gao et al. [11] & 97 & 232 & 100 & 178 & 27 & 22 & 294 & 642 & 154 & 222 \\
\hline Jakubowska et al. [38] & 1155 & 334 & 465 & 130 & 44 & 19 & 2775 & 798 & 553 & 168 \\
\hline Pawlik et al. [42] & 67 & 63 & 55 & 79 & 13 & 18 & 189 & 205 & 81 & 115 \\
\hline Zhang et al. [9] & 102 & 115 & 94 & 92 & 19 & 11 & 298 & 322 & 132 & 114 \\
\hline
\end{tabular}

Table 2: The distribution of MTHFR C677T genotypes and allele numbers in ovary cancer cases and controls.

studies with high p values. Control population of one study [38] was not in HW equilibrium and heterogeneity did not decreased after exclusion of that study ( $\mathrm{p}=0.007, \mathrm{I}^{2}=65.99 \%$ ). Exclusion of one study with small sample size, less than 100 [41], also did not decreased heterogeneity $\left(\mathrm{P}_{\text {heterogeneity }}=0.001, \mathrm{I}^{2}=65.49 \%\right)$. Similarly exclusion of five studies with very high $\mathrm{p}$ value $[18,19,38,39]$ did not decrease heterogeneity $\left(\mathrm{P}_{\text {heterogeneity }}=0.007, \mathrm{I}^{2}=65.99 \%\right)$ but increased odds ratio $(\mathrm{OR}=1.27,95 \%$ $\mathrm{CI}=1.04-1.51 \mathrm{p}=0.02)$ and showed significant association between C677T polymorphism and ovary cancer with allele contrast model (Figures 1 and 2).

\section{Publication bias}

Funnel plots, Begg's and Egger's test were performed to estimate the risk of publication bias. The shape of funnel plots in all contrast models showed obvious evidence of symmetry (Figure 3 ). In addition, all the $P$ values of Egger's test were more than 0.05 , which provided statistical evidence for the symmetry of funnel plots in the meta-analysis $(\mathrm{p}=0.24$ for T vs. C; $\mathrm{p}=0.95$ for TT vs. CC; and $\mathrm{p}=0.29$ for CT vs. CC; $\mathrm{p}=0.46$ for $\mathrm{TT}+\mathrm{CT}$ vs. $\mathrm{CC} ; \mathrm{p}=0.64$ for TT vs. $\mathrm{CT}+\mathrm{CC})$ (Table 3$)$. Begg's test results also did not show publication bias ( $\mathrm{p}=0.29$ for $\mathrm{T}$ vs. $\mathrm{C} ; \mathrm{p}=0.49$ for TT vs. CC; and $\mathrm{p}=0.24$ for $\mathrm{CT}$ vs. CC; $\mathrm{p}=0.24$ for $\mathrm{TT}+\mathrm{CT}$ vs. $\mathrm{CC} ; \mathrm{p}=0.54$ for TT vs. CT+CC) (Table 4).

\section{Discussion}

Present meta-analysis of the association of the MTHFR C677T polymorphism with ovary cancer investigated 5,922 patients and 5,235 controls from 11 case-control studies. Overall meta-analysis did not detect significant genetic association between the MTHFR C677T polymorphism and ovarian cancer.

Folate, methionine, vitamin B6 and vitamin B12 may influence carcinogenesis due to their roles in the one-carbon metabolism pathway which is critical for DNA synthesis, methylation and repair. However, DNA synthesis is also integral to the process of tumor formation, and for many years anti-folates have been used to treat some cancers. Recent studies have suggested that rather than preventing cancer, high folate levels might promote progression of pre-neoplastic lesions to cancer (Table 5) [19], and that the introduction of mandatory folate fortification in Canada and the United States of America may have led to increases in colorectal cancer rates [19].

Epidemiologic studies have revealed that MTHFR polymorphisms are associated with an increased risk of esophageal cancer, gastric cancer, breast cancer, hepatocellular carcinoma, bladder cancer, and prostate cancer. Conversely, MTHFR polymorphisms have also been associated with a reduced risk of colon cancer, leukemia, and highly aggressive prostate cancer [43-46]. MTHFR plays a central role in balancing DNA synthesis (which involves 5,10-methylentetrahydrofolate) and DNA methylation (which involves 5,10-methyltetrahydrofolate). Specifically, the $677 \mathrm{~T}$ allele contributes to DNA hypomethylation, which in turn may lead to altered gene expression. This polymorphism might exert a protective effect, as observed for colorectal cancer [47], by increasing the levels of the MTHFR substrate, essential for DNA synthesis. The substrate of MTHFR enzyme, 5,10-methylenetetrahydrofolate, is involved in the conversion of deoxyuridylate monophosphate to deoxythymidylate monophosphate, and low levels of 5,10-methylenetetrahydrofolate would lead to an increased deoxyuridylate monophosphate/deoxythymidylate monophosphate ratio. In this situation, increased incorporation of uracil into DNA in place of thymine may follow, resulting in an increased chance of point mutations and DNA/chromosome breakage [48]. A less active form of MTHFR would lead, all other factors being equal, to an accumulation of 5,10-methylenetetrahydrofolate, thus a lower deoxyuridylate monophosphate/deoxythymidylate monophosphate ratio, and a presumably lower cancer risk [48]. 
Citation: Rai V (2016) Methylenetetrahydrofolate Reductase Gene C677T Polymorphism and Its Association with Ovary Cancer. J Health Med Informat 7: 226. doi:10.4172/2157-7420.1000226

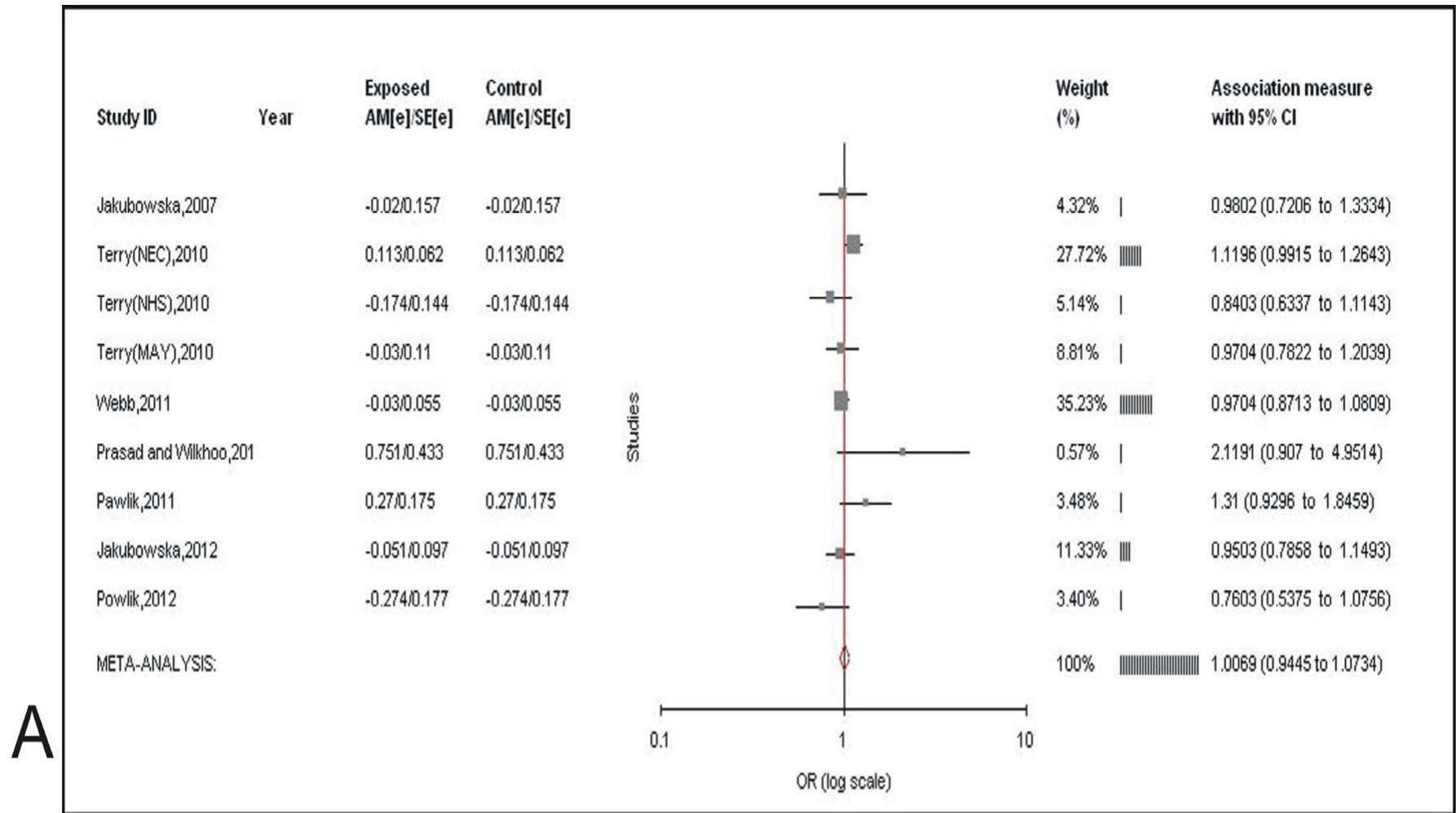
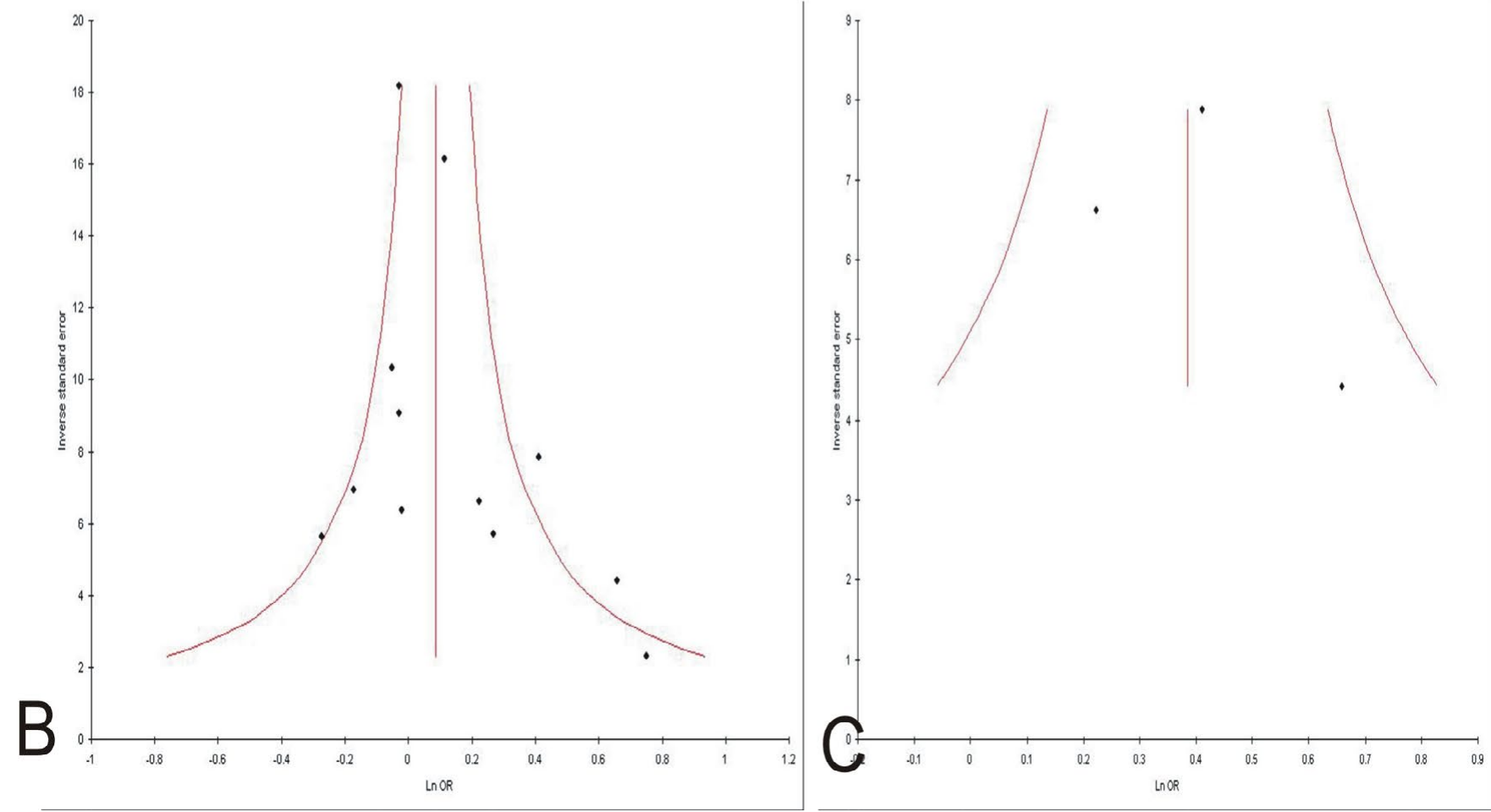

Figure 1: A) Forest plot for the association between MTHFR C677T polymorphism and ovary cancer for allele contrast model (T vs. C) with random effect model, B Funnel plot precision versus OR (T vs. C), C) standard error versus OR (T vs. C) in total studies. 
Citation: Rai V (2016) Methylenetetrahydrofolate Reductase Gene C677T Polymorphism and Its Association with Ovary Cancer. J Health Med Informat 7: 226. doi:10.4172/2157-7420.1000226
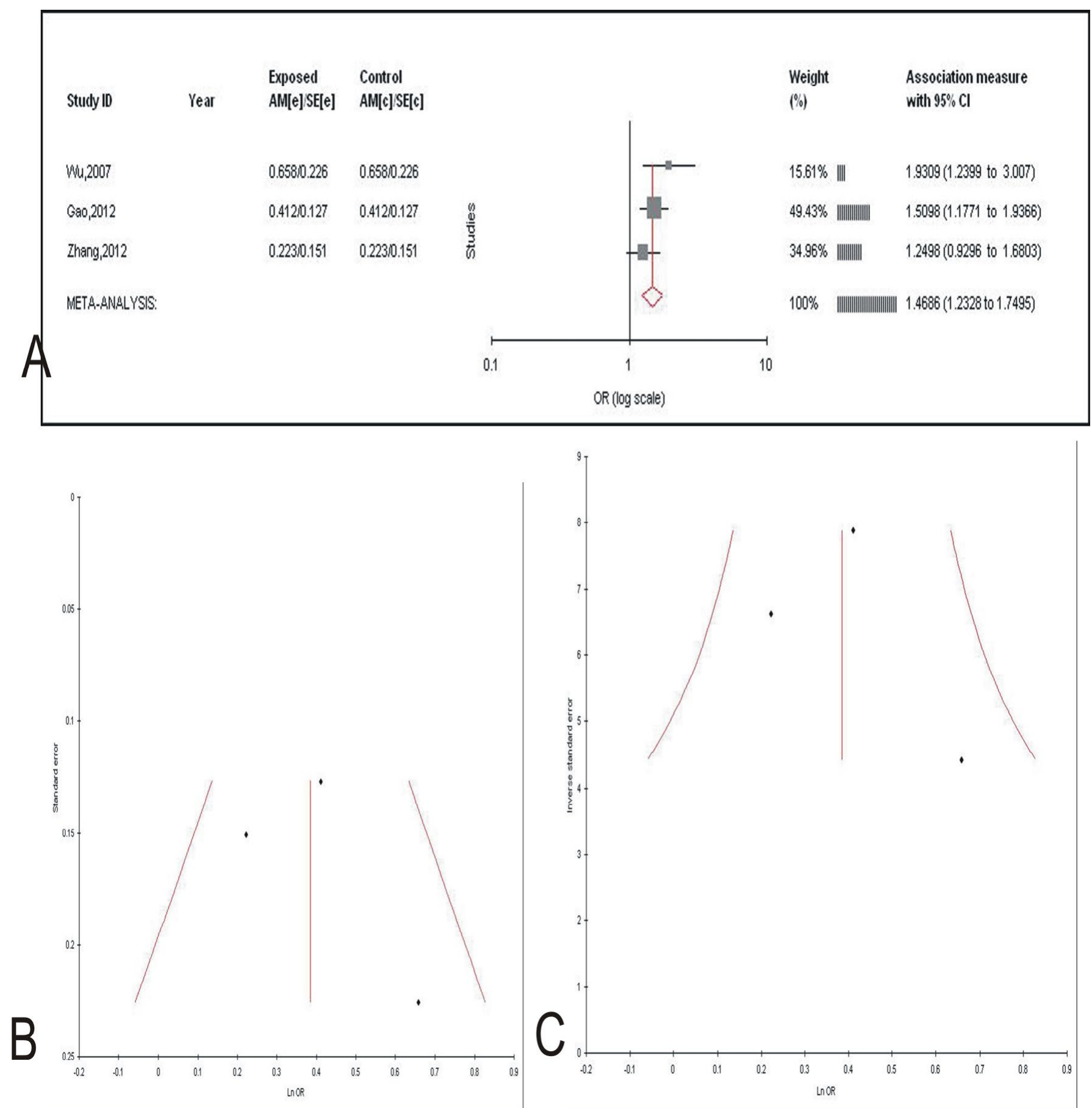

Figure 2: A) Forest plot for the association between MTHFR C677T polymorphism and ovary cancer for allele contrast model (T vs. C) with fixed effect model, B Funnel plot precision versus OR (T vs. C), C) standard error versus OR (T vs. C) in Asian studies.

Meta-analysis provides a standardized approach for examining the existing literature on a specific, possibly controversial, issue to determine whether a conclusion can be reached regarding the effect of a polymorphism of low penetrant gene [49]. Several meta-analyses were published to assess the role of MTHFR polymorphism in cancer development like: breast cancer [50,51] lung cancer [52] colorectal cancer [53] pancreatic cancer [54] Esophageal cancer [55,56] and cervical cancer [57].
There were several limitations in present study: 1) Crude ORs was used in the pooled analysis without adjustment; 2) The robustness of every single study would be affected by the technique they used; 3 ) The relatively small sample sizes of some studies is included in the analysis; 4) Meta-analysis was restricted on only single polymorphism, other polymorphism of folate pathway genes should also be included in future meta-analysis and 5) Except one genetic polymorphism, other important factors such as age, ethnicity, and folate intake, and 
Citation: Rai V (2016) Methylenetetrahydrofolate Reductase Gene C677T Polymorphism and Its Association with Ovary Cancer. J Health Med Informat 7: 226. doi:10.4172/2157-7420.1000226

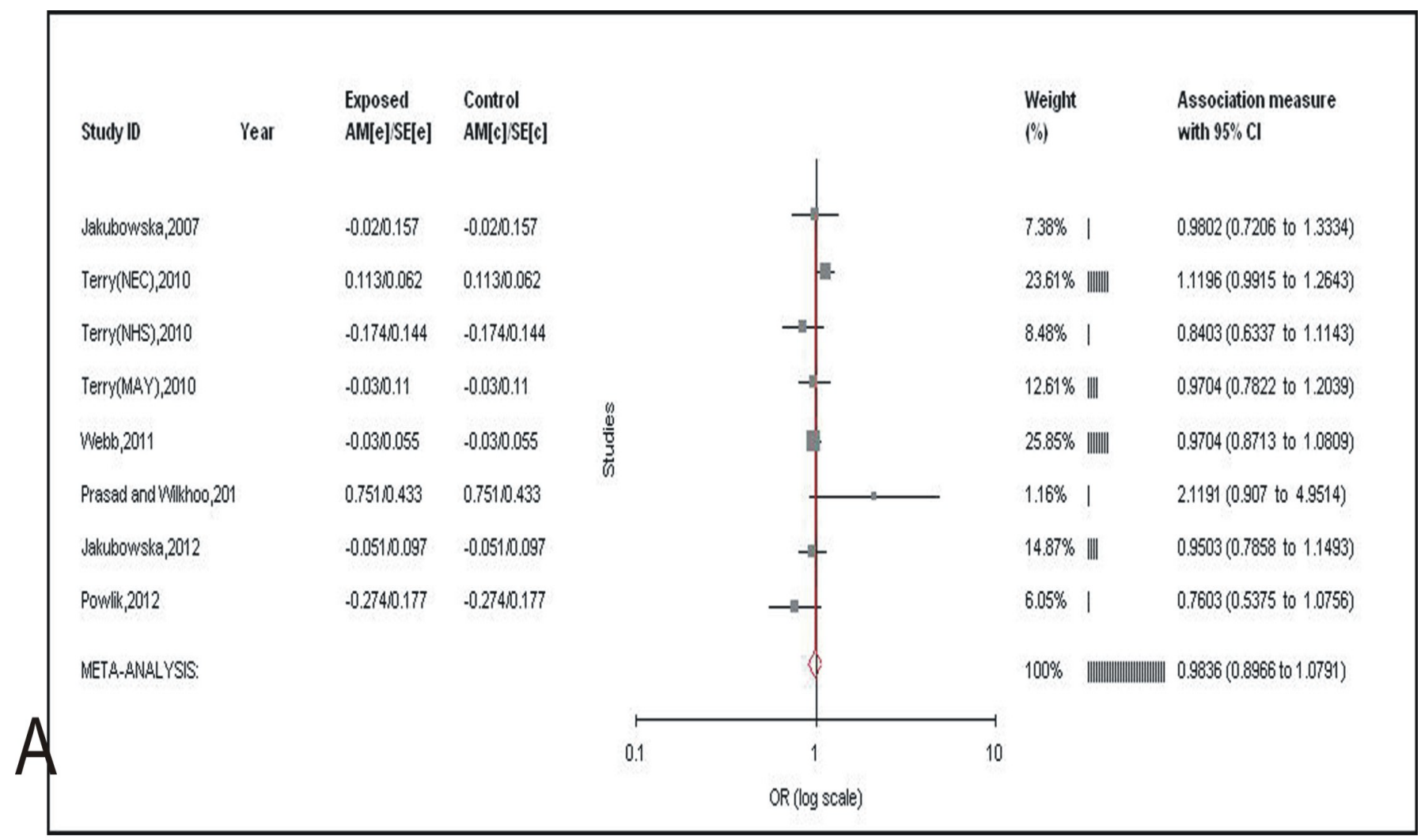

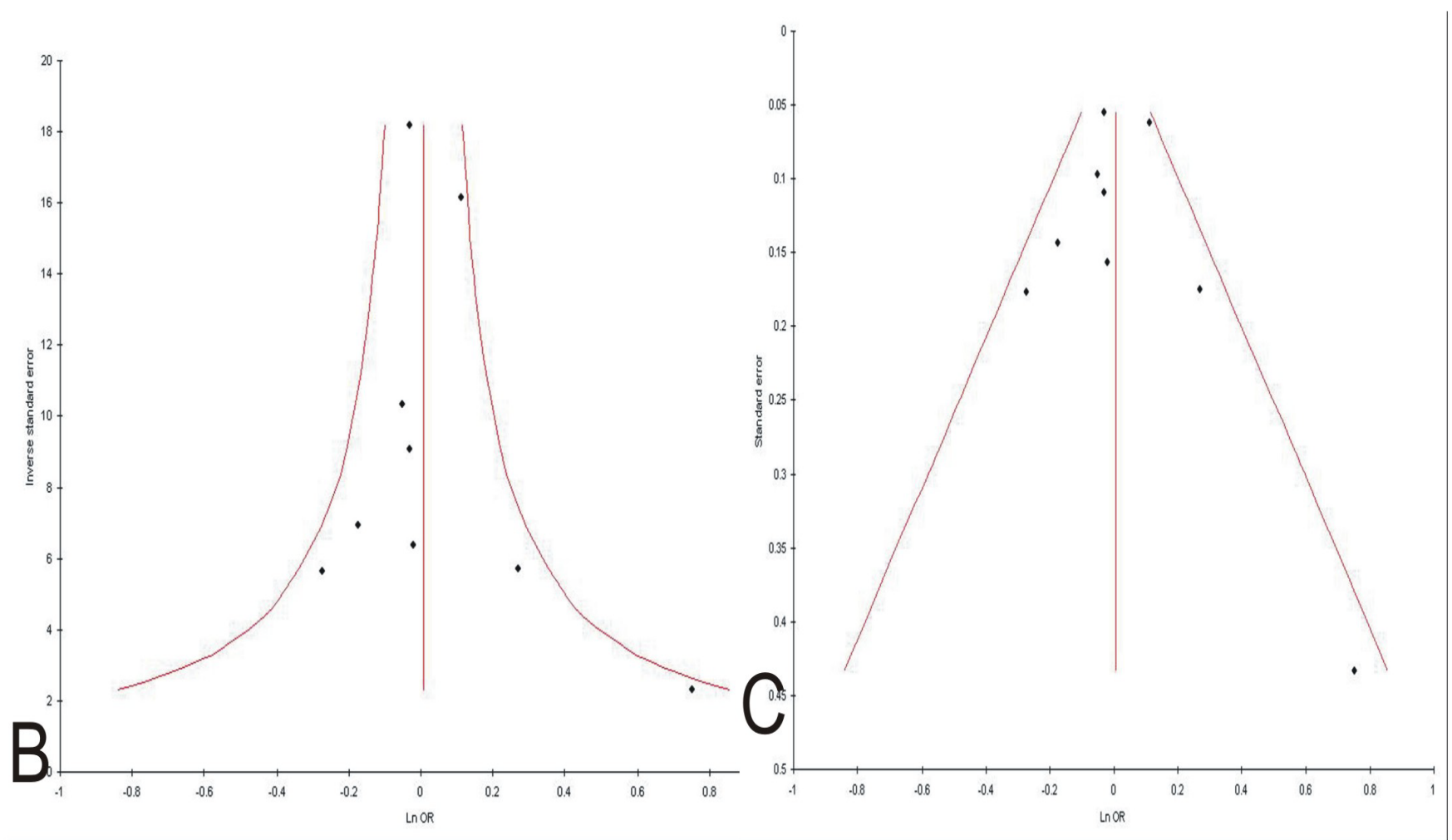

Figure 3: A) Forest plot for the association between MTHFR C677T polymorphism and ovary cancer for allele contrast model (T vs. C) with fixed effect model, B) Funnel plot precision versus OR (T vs. C), C) standard error versus OR (T vs. C) in Caucasian studies. 
Citation: Rai V (2016) Methylenetetrahydrofolate Reductase Gene C677T Polymorphism and Its Association with Ovary Cancer. J Health Med Informat 7: 226. doi:10.4172/2157-7420.1000226

Page 7 of 8

\begin{tabular}{|c|c|c|c|c|c|}
\hline \multirow{2}{*}{ Genetic Models } & Fixed effect & Random effect & \multirow{2}{*}{$\begin{array}{l}\text { Heterogeneity } p \text {-value } \\
\text { ( } Q \text { test) }\end{array}$} & \multirow{2}{*}{$I^{2}(\%)$} & \multirow{2}{*}{$\begin{array}{l}\text { Publication Bias (p of } \\
\text { Egger's test) }\end{array}$} \\
\hline & OR (95\% Cl), p & OR $(95 \% \mathrm{Cl}), \mathrm{p}$ & & & \\
\hline Allele Contrast (T vs. C) & $1.04(0.99-1.11), 0.90$ & $1.08(0.95-1.22), 0.15$ & 0.0009 & 66.2 & 0.32 \\
\hline Co-dominant (CT vs. CC) & $1.02(0.91-1.14), 0.68$ & $1.01(0.85-1.20), 0.90$ & 0.03 & 46.9 & 0.29 \\
\hline Homozygoote (TT vs. CC) & 0.99 (0.86-1.14), 0.90 & 1.02 (0.75-1.37), 0.91 & 0.0002 & 69.55 & 0.95 \\
\hline Dominant (TT+CT vs. CC) & 1.02 (0.91-1.13), 0.75 & 1.01 (0.83-1.21), 0.93 & 0.006 & 57.96 & 0.46 \\
\hline Recessive (TT vs. $C T+C C$ ) & 0.99 (0.90-1.08), 0.79 & 1.03 (0.85-1.23), 0.76 & 0.001 & 63.42 & 0.64 \\
\hline
\end{tabular}

Table 3: Summary estimates for the odds ratio (OR) of MTHFR C677T in various allele/genotype contrasts, the significance Level ( $p$ value) of heterogeneity test ( $Q$ test) and the $\mathrm{I}^{2}$ metric and publication bias $\mathrm{p}$-value (Egger test) in total studies.

\begin{tabular}{|c|c|c|c|c|c|}
\hline Genetic Models & $\begin{array}{l}\text { Fixed effect } \\
\text { OR }(95 \% \mathrm{Cl}), \mathrm{p}\end{array}$ & $\begin{array}{l}\text { Random effect } \\
\text { OR }(95 \% \mathrm{Cl}), p\end{array}$ & $\begin{array}{c}\text { Heterogeneity } \\
\text { p-value (Q } \\
\text { test) }\end{array}$ & $I^{2}(\%)$ & $\begin{array}{c}\text { Publication Bias (p of } \\
\text { Egger's test) }\end{array}$ \\
\hline Allele Contrast ( $\mathrm{T}$ vs. $\mathrm{C}$ ) & $1.47(1.23-1.74),<0.0001$ & 1.48 (1.20-1.81), 0.0002 & 0.26 & 24.68 & 0.61 \\
\hline Co-dominant (Ct vs. CC) & 1.18 (0.92-1.5), 0.19 & $1.14(0.82-1.56), 0.42$ & 0.22 & 33.11 & 0.10 \\
\hline Homozygoote (TT vs. CC) & $1.46(0.97-2.19), 0.06$ & $1.21(0.33-4.54), 0.77$ & 0.0001 & 88.99 & 0.32 \\
\hline Dominant (TT+CT vs. CC) & 1.25 (0.99-1.57), 0.06 & $1.1(0.64-1.8), 0.8$ & 0.02 & 74.93 & 0.06 \\
\hline Recessive (TT vs. CT+CC) & $1.28(0.88-1.85), 0.2$ & $1.24(0.39-3.87), 0.7$ & 0.0002 & 88.16 & 0.72 \\
\hline
\end{tabular}

Table 4: Summary estimates for the odds ratio (OR) of MTHFR C677T in various allele/genotype contrasts, the significance level ( $p$ value) of heterogeneity test ( $Q$ test) and the $\mathrm{I}^{2}$ metric and publication bias p-value (Egger test) in Asian population.

\begin{tabular}{|c|c|c|c|c|c|}
\hline Genetic models & $\begin{array}{l}\text { Fixed effect } \\
\text { OR (95\% CI), p }\end{array}$ & $\begin{array}{l}\text { Random effect } \\
\text { OR }(95 \% \mathrm{Cl}), p\end{array}$ & $\begin{array}{c}\text { Heterogeneity } \\
\text { p-value ( } Q \\
\text { test) }\end{array}$ & $I^{2}(\%)$ & $\begin{array}{c}\text { Publication Bias (p of } \\
\text { Egger's test) }\end{array}$ \\
\hline Allele Contrast (T vs. C) & 1.001 (0.94-1.07), 0.83 & 0.99 (0.90-1.09), 0.98 & 0.10 & 39.33 & 0.87 \\
\hline Co-dominant (Ct vs. CC) & $0.99(0.87-1.11), 0.83$ & 0.97 (0.79-1.19), 0.78 & 0.04 & 50.28 & 0.41 \\
\hline Homozygoote (TT vs. CC) & 0.94 (0.81-1.09), 0.42 & 0.95 (0.75-1.18), 0.63 & 0.10 & 40.03 & 0.71 \\
\hline Dominant (TT+CT vs. CC) & 0.96 (0.86-1.05), 0.55 & $0.96(0.8-1.16), 0.7$ & 0.07 & 44.27 & 0.64 \\
\hline Recessive (TT vs. CT+CC) & 0.97 (0.88-1.06), 0.5 & $0.98(0.86-1.11), 0.76$ & 0.20 & 27 & 0.90 \\
\hline
\end{tabular}

Table 5: Summary estimates for the odds ratio (OR) of MTHFR C677T in various allele/genotype contrasts, the significance level ( $p$ value) of heterogeneity test ( $Q$ test) and the $\mathrm{I}^{2}$ metric and publication bias p-value (Egger test) in Caucasian population.

smoking status were not considered. Present meta-analysis had several strength also like- (i) The publication bias was not detected in present meta-analysis, (ii) Pooled number of cases and controls from different studies significantly increased the statistical power of the analysis, (iii) Distribution of genotypes in controls except one study was in HardyWeinberg equilibrium.

In summary, the results of current meta-analysis indicated a lack of association between MTHFR C677T gene polymorphism and ovary cancer. The results of the present meta-analysis were based on relatively small numbers of studies, participants and higher between studies heterogeneity, hence must be interpreted with caution.

\section{Acknowledgment}

The authoress is highly grateful to Leon Bax (Chief Scientific Officer at BiostatXL, UMC Utrecht) for his valuable suggestions, which help her in statistical analysis.

\section{References}

1. Bray F, Jemal A, Grey N, Ferlay J, Forman D (2012) Global cancer transitions according to the Human Development Index (2008-2030): a population-based study. Lancet Oncol 13: 790-801.

2. Lajin B, Alachkar A (2013) The NQO1 polymorphism C609T (Pro187Ser) and cancer susceptibility: a comprehensive meta-analysis. Br J Cancer 109: 13251337.

3. Permuth-Wey J, Sellers TA (2009) Epidemiology of ovarian cancer. Methods Mol Biol 472: 413-437.

4. Swisher EM, Gonzalez RM, Taniguchi T, Garcia RL, Walsh T, et al. (2009) Methylation and protein expression of DNA repair genes: association with chemotherapy exposure and survival in sporadic ovarian and peritoneal carcinomas. Mol Cancer 8: 48.

5. Asadollahi R, Hyde CA, Zhong XY (2010) Epigenetics of ovarian cancer: from the lab to the clinic. Gynecol Oncol 118: 81-87.
6. Darehdori AS, Dastjerdi MN, Dahim H, Slahshoor M, Babazadeh Z, et al. (2012) Lack of significance of the BRCA2 promoter methylation status in different genotypes of the MTHFR a1298c polymorphism in ovarian cancer cases in Iran. Asian Pac J Cancer Prev 13: 1833-1836.

7. Jin F, Shu XO, Devesa SS, Zheng W, Blot WJ, et al. (1993) Incidence trends for cancers of the breast, ovary, and corpus uteri in urban Shanghai, 1972-89. Cancer Causes Control 4: 355-360.

8. La Vecchia C (2001) Epidemiology of ovarian cancer: a summary review. Eur J Cancer Prev 10: 125-129.

9. Zhang L, Liu W, Hao Q, Bao L, Wang K (2012) Folate intake and methylenetetrahydrofolate reductase gene polymorphisms as predictive and prognostic biomarkers for ovarian cancer risk. Int J Mol Sci 13: 4009-4020.

10. Zhang M, Xie X, Lee AH, Binns CW (2004) Soy and isoflavone intake are associated with reduced risk of ovarian cancer in southeast china. Nutr Cance 49: $125-130$.

11. Gao S, Liu N, Ma Y, Ying L (2012) Methylenetetrahydrofolate reductase gene polymorphisms as predictive and prognostic biomarkers in ovarian cancer risk Asian Pac J Cancer Prev 13: 569-573.

12. Negri E, La Vecchia C, Franceschi S, Levi F, Parazzini F (1996) Intake of selected micronutrients and the risk of endometrial carcinoma. Cancer 77 917-923.

13. McCann SE, Freudenheim JL, Marshall JR, Graham S (2003) Risk of human ovarian cancer is related to dietary intake of selected nutrients, phytochemicals and food groups. J Nutr 133: 1937-1942.

14. Xu WH, Shrubsole MJ, Xiang YB, Cai Q, Zhao GM, et al. (2007) Dietary folate intake, MTHFR genetic polymorphisms, and the risk of endometrial cance among Chinese women. Cancer Epidemiol Biomarkers Prev 16: 281-287.

15. Larsson SC, Giovannucci E, Wolk A (2004) Dietary folate intake and incidence of ovarian cancer: the Swedish Mammography Cohort. J Natl Cancer Inst 96 396-402.

16. Navarro Silvera SA, Jain M, Howe GR, Miller AB, Rohan TE (2006) Dietary folate consumption and risk of ovarian cancer: a prospective cohort study. Eur J Cancer Prev 15: 511-515. 
Citation: Rai V (2016) Methylenetetrahydrofolate Reductase Gene C677T Polymorphism and Its Association with Ovary Cancer. J Health Med Informat 7: 226. doi:10.4172/2157-7420.1000226

17. Tworoger SS, Hecht JL, Giovannucci E, Hankinson SE (2006) Intake of folate and related nutrients in relation to risk of epithelial ovarian cancer. Am J Epidemiol 163: 1101-1111.

18. Terry KL, Tworoger SS, Goode EL, Gates MA, Titus-Ernstoff L, et al. (2010) MTHFR polymorphisms in relation to ovarian cancer risk. Gynecol Oncol 119: 319-324

19. Webb PM, Ibiebele TI, Hughes MC, Beesley J, van der Pols JC, et al. (2011) Folate and related micronutrients, folate-metabolising genes and risk of ovarian cancer. Eur J Clin Nutr 65: 1133-1140.

20. Hobbs CA, Sherman SL, Yi P, Hopkins SE, Torfs CP, et al. (2000) Polymorphisms in genes involved in folate metabolism as maternal risk factors for Down syndrome. Am J Hum Genet 67: 623-630.

21. Frosst $P$, Blom HJ, Milos R, Goyette $P$, Sheppard CA, et al. (1995) A candidate genetic risk factor for vascular disease: a common mutation in methylenetetrahydrofolate reductase. Nat Genet 10: 111-113.

22. Bagley PJ, Selhub J (1998) A common mutation in the methylenetetrahydrofolate reductase gene is associated with an accumulation of formylated tetrahydrofolates in red blood cells. Proc Natl Acad Sci U S A 95: 13217-13220.

23. Brattström L, Wilcken DE, Ohrvik J, Brudin L (1998) Common methylenetetrahydrofolate reductase gene mutation leads to hyperhomocysteinemia but not to vascular disease: the result of a metaanalysis. Circulation 98: 2520-2526.

24. van der Put NM, Eskes TK, Blom HJ (1997) Is the common 677C-->T mutation in the methylenetetrahydrofolate reductase gene a risk factor for neural tube defects? A meta-analysis. QJM 90: 111-115.

25. Blanton SH, Henry RR, Yuan Q, Mulliken JB, Stal S, et al. (2011) Folate pathway and nonsyndromic cleft lip and palate. Birth Defects Res A Clin Mol Teratol 91: 50-60.

26. Benes P, Kanková K, Muzík J, Groch L, Benedík J, et al. (2001) Methylenetetrahydrofolate reductase polymorphism, type II diabetes mellitus, coronary artery disease, and essential hypertension in the Czech population. Mol Genet Metab 73: 188-195.

27. Zhang Y, Chen GQ, Ji Y, Huang B, Shen WS, et al. (2012) Quantitative assessment of the effect of MTHFR polymorphisms on the risk of lung carcinoma. Mol Biol Rep 39: 6203-6211.

28. Mantel N, Haenszel W (1959) Statistical aspects of the analysis of data from retrospective studies of disease. J Natl Cancer Inst 22: 719-748.

29. DerSimonian R, Laird N (1986) Meta-analysis in clinical trials. Control Clin Trials 7: 177-188

30. Whitehead A (2002) Meta-analysis of controlled clinical trials. Wiley, Chichester UK.

31. Thakkinstian A, McEvoy M, Minelli C, Gibson P, Hancox B, et al. (2005) Systematic review and meta-analysis of the association between \{beta\}2adrenoceptor polymorphisms and asthma: a HuGE review. Am J Epidemio 162: 201-211.

32. Higgins JP, Thompson SG (2002) Quantifying heterogeneity in a meta-analysis Stat Med 21: 1539-1558.

33. Higgins JP, Thompson SG, Deeks JJ, Altman DG (2003) Measuring inconsistency in meta-analyses. BMJ 327: 557-560.

34. Guo J, Jin M, Zhang M, Chen K (2012) A genetic variant in miR-196a2 increased digestive system cancer risks: a meta-analysis of 15 case-control studies. PLoS One 7: e30585.

35. Begg CB, Mazumdar M (1994) Operating characteristics of a rank correlation test for publication bias. Biometrics 50: 1088-1101.

36. Egger M, Davey Smith G, Schneider M, Minder C (1997) Bias in meta-analysis detected by a simple, graphical test. BMJ 315: 629-634.

37. Bax L, Yu LM, Ikeda N, Tsuruta H, Moons KG (2006) Development and validation of MIX: comprehensive free software for meta-analysis of causal research data. BMC Med Res Methodol 6: 50

38. Jakubowska A, Gronwald J, Menkiszak J, Górski B, Huzarski T, et al (2007) Methylenetetrahydrofolate reductase polymorphisms modify BRCA1associated breast and ovarian cancer risks. Breast Cancer Res Treat 104: 299-308
39. Jakubowska A, Rozkrut D, Antoniou A, Hamann U, Scott RJ, et al. (2012) Association of PHB $1630 \mathrm{C}>\mathrm{T}$ and MTHFR $677 \mathrm{C}>\mathrm{T}$ polymorphisms with breast and ovarian cancer risk in BRCA1/2 mutation carriers: results from a multicenter study. Br J Cancer 106: 2016-2024.

40. Wu Y, Zhang JY, Zuo WJ (2007) Xian Dai Fu Chan Ke Jin Zhan 16: 811-813.

41. Prasad VV, Wilkhoo $H$ (2011) Association of the functional polymorphism C677T in the methylenetetrahydrofolate reductase gene with colorectal thyroid, breast, ovarian, and cervical cancers. Onkologie 34: 422-426.

42. Pawlik P, Mostowska A, Lianeri M, Sajdak S, Kedzia H, et al. (2012) Folate and choline metabolism gene variants in relation to ovarian cancer risk in the Polish population. Mol Biol Rep 39: 5553-5560.

43. Larsson SC, Håkansson N, Giovannucci E, Wolk A (2006) Folate intake and pancreatic cancer incidence: a prospective study of Swedish women and men. J Natl Cancer Inst 98: 407-413.

44. Lin D1, Li H, Tan W, Miao X, Wang L (2007) Genetic polymorphisms in folatemetabolizing enzymes and risk of gastroesophageal cancers: a potential nutrient-gene interaction in cancer development. Forum Nutr 60: 140-145.

45. Kouidhi S, Rouissi K, Khedhiri S, Ouerhani S, Cherif M, et al. (2011) MTHFR gene polymorphisms and bladder cancer susceptibility: a meta-analysis including race, smoking status and tumour stage. Asian Pac J Cancer Prev 12: $2227-2232$

46. Ma C, Liu Y, Zhang W, Liu P (2013) The association between MTHFR C677 polymorphism and ovarian cancer risk: a meta-analysis of 18,628 individuals. Mol Biol Rep 40: 2061-2068.

47. Botto LD, Yang Q (2000) 5,10-Methylenetetrahydrofolate reductase gene variants and congenital anomalies: a HuGE review. Am J Epidemiol 151: 862 877

48. Blount BC, Mack MM, Wehr CM, MacGregor JT, Hiatt RA, et al. (1997) Folate deficiency causes uracil misincorporation into human DNA and chromosome breakage: implications for cancer and neuronal damage. Proc Natl Acad Sci U S A 94: 3290-3295.

49. Russo MW (2007) How to Review a Meta-analysis. Gastroenterol Hepatol (N Y) 3: 637-642

50. Liang $\mathrm{H}$, Yan Y, Li T, et al (2013) Tumor Biology.

51. Rai V (2014) The methylenetetrahydrofolate reductase C677T polymorphism and breast cancer risk in Asian populations. Asian Pac J Cancer Prev 15: 5853-5860.

52. Rai V (2014) Folate pathway gene MTHFR C677T polymorphism and risk of lung cancer in Asian populations. Asian Pac J Cancer Prev 15: 9259-9264.

53. Hubner RA, Houlston RS (2007) MTHFR C677T and colorectal cancer risk: A meta-analysis of 25 populations. Int J Cancer 120: 1027-1035.

54. Tu YL, Wang SB, Tan XL (2012) MTHFR gene polymorphisms are not involved in pancreatic cancer risk: a meta-analysis. Asian Pac J Cancer Prev 13: 4627

55. Liu YX, Wang B, Wan MH, Tang WF, Huang FK, et al. (2011) Meta-analysis of the relationship between the Metholenetetrahydrofolate reductase C677T genetic polymorphism, folate intake and esophageal cancer. Asian Pac J Cancer Prev 12: 247-252.

56. Wen YY, Yang SJ, Zhang JX, Chen XY (2013) Methylenetetrahydrofolate reductase genetic polymorphisms and esophageal squamous cell carcinoma susceptibility: a meta-analysis of case-control studies. Asian Pac J Cancer Prev 14: 21-25.

57. Mei Q, Zhou D, Gao J, Shen S, Wu J, et al. (2012) The association between MTHFR $677 \mathrm{C}>\mathrm{T}$ polymorphism and cervical cancer: evidence from a metaanalysis. BMC Cancer 12: 467 